\title{
Untreated asymptomatic bacteriuria in girls: II-Effect of phenoxymethylpenicillin and erythromycin given for intercurrent infections
}

\author{
Sverker Hansson, Ulf Jodal, Knut Lincoln, Catharina Svanborg-Edén
}

Abstract

Objective-To investigate the effects of phenoxymethylpenicillin and erythromycin on urinary isolates from patients with untreated asymptomatic bacteriuria.

Design-Retrospective study of subgroup of patients from cohort followed up till the end of 1986.

Setting-Outpatient clinic for children with urinary tract infections.

Patients - 51 Girls aged under 15 with untreated asymptomatic bacteriuria.

Interventions-Before 1982 intercurrent infections (mostly tonsillitis or otitis) were treated with phenoxymethylpenicillin; after 1982 erythromycin treatment was preferred.

End points - Change of bacterial strain in urinary tract and symptomatic recurrences of disease.

Measurements and main results-Bacteria identified by serotype and electrophoretic type and compared before and after antibiotic treatment. Bacteriuria eradicated and replaced by new strains in most patients treated with phenoxymethylpenicillin, leading to symptomatic recurrences in about $15 \%$. Conversely, patients given erythromycin rarely showed change in bacteriuria and none suffered symptomatic recurrence.

Conclusions-In girls with untreated asymptomatic bacteriuria the use of phenoxymethylpenicillin for intercurrent infections may lead to a change of urinary bacteria and leave them at substantial risk of acute pyelonephritis. With erythromycin this risk is small ( $2 / 20$ courses in this series).

\section{Introduction}

In a study of asymptomatic bacteriuria in nonpregnant women Asscher et al found that symptoms developed significantly more often in those with reinfections after treatment than in those with persisting or relapsing bacteriuria. ${ }^{1}$ Also in schoolgirls treatment of asymptomatic bacteriuria was sometimes followed by symptomatic urinary tract infection..$^{2-5}$ For example, in the study by Lindberg et al 10 out of 78 girls had symptomatic recurrences. ${ }^{3}$ Furthermore, non-treatment of girls with asymptomatic bacteriuria and normal kidneys did not lead to renal damage or impaired renal growth. ${ }^{3.5}$ As no beneficial effects were produced by treatment, it was suggested that schoolgirls with asymptomatic bacteriuria and normal urinary tracts were better left untreated. ${ }^{6}$

TABLE I-Clinical characteristics of patients with asymptomatic bacteriuria treated with phenoxymethylpenicillin and erythromycin

\begin{tabular}{lcc}
\hline & $\begin{array}{c}\text { Phenoxymethylpenicillin } \\
(\mathrm{n}=40)\end{array}$ & $\begin{array}{c}\text { Erythromycin } \\
(\mathrm{n}=16)\end{array}$ \\
\hline Median age (years) (range) & $9 \cdot 4(4 \cdot 8-14 \cdot 7)$ & $9 \cdot 0(5 \cdot 6-13 \cdot 2)$ \\
No with previous pyelonephritis & 20 & 14 \\
No with vesicoureteric reflux & $13^{\star}$ & $3^{\star}$ \\
No with renal scarring & 6 & 4
\end{tabular}

$\star$ One patient in each group was not investigated with voiding cystourethrography.
Children with untreated bacteriuria may, however, need antibacterial agents for other infections-for example, otitis media or tonsillitis - which may lead to unintentional eradication of bacteriuria (Hansson et al, accompanying paper $\mathrm{p} 853$ ). This study compares the effects of phenoxymethylpenicillin and erythromycin on the urinary flora.

\section{Patients and methods}

The patients were among a cohort of children being followed up in the outpatient clinic for urinary tract infections at the Children's Hospital, Gothenburg.? The city of Gothenburg has a population of about 425000 , of whom some 80000 are children aged under 16. There is only one children's hospital in the city. Ten outpatient clinics staffed by 20 district paediatricians operate regular office hours, with limited capacity to handle acute cases, and there are no general practitioners specialising in the care of children. Most children with acute diseases are therefore seen in the emergency room at the hospital. Only a minority of children with urinary tract infections are managed within the district organisation.

Children with untreated bacteriuria are followed up in the clinic every three to six months. Each visit includes a careful history concerning fever, symptoms of infection, and antibiotic treatment; urine analysis and culture; and measurement of serum $C$ reactive protein concentration. At least yearly the maximal concentrating capacity is measured by the desmopressin test. ${ }^{78}$ All Gram negative bacteria are saved as deep agar stab cultures.

Diagnostic criteria-The criterion for a diagnosis of asymptomatic bacteriuria was two urine cultures containing $\geqslant 100 \times 10^{6}$ bacteria/l in a patient without symptoms. The criteria for acute pyelonephritis were one urine culture containing $\geqslant 100 \times 10^{6}$ bacteria/l, fever $\geqslant 38.5^{\circ} \mathrm{C}$, and either a $\mathrm{C}$ reactive protein concentration $>20 \mathrm{mg} / \mathrm{l}$, a microsedimentation rate $\geqslant 25 \mathrm{~mm}$ in the first hour, or a transiently decreased concentrating capacity. ${ }^{8}$ The criteria for acute cystitis were bacteriuria $\geqslant 100 \times 10^{6}$ bacteria/l, acute symptoms of dysuria and frequency, and normal laboratory findings. Scarring was defined as described by Hodson and Wilson. ${ }^{9} \mathrm{~A}$ change in bacterial strain was defined by a change in $\mathrm{O}$ type or differences in expressed enzyme activity on multilocus electrophoresis (see accompanying paper).

Children studied-At the end of 1986 we had followed up 229 children aged under 16 with untreated bacteriuria of at least three months' duration. Among these we identified retrospectively 51 girls with ongoing, untreated bacteriuria caused by Escherichia coli who had been treated with phenoxymethylpenicillin or erythromycin for other infections - for example, otitis media or tonsillitis. Forty girls had received a total of 46 courses of phenoxymethylpenicillin and 16 girls 20 courses of erythromycin. Five girls had therefore received both types of treatment. Table I gives the characteristics of the two groups. 
Antimicrobials-In Sweden phenoxymethylpenicillin (penicillin V) is the most commonly used antibacterial for tonsillitis and otitis media. In 1982, however, after finding that treatment with this agent often led to unintentional eradication of bacteriuria (see accompanying paper), we started to use erythromycin as the preferred drug for intercurrent infections.

Bacterial analysis-All Gram negative bacteria were saved as deep agar stab cultures. Urine was collected as clean catch midstream samples. Typing was performed by standard procedures. Antibiotic sensitivity was tested by the disc diffusion method ${ }^{10}$ with antibiotic sensitivity medium and discs containing ampicillin (10 $\mu \mathrm{g})$, penicillin $(10 \mu \mathrm{g})$, or erythromycin $(15 \mu \mathrm{g})(\mathrm{AB}$ Biodisc, Solna, Sweden). Resistance to the antibiotics was defined as minimal inhibitory concentrations exceeding 16,4 , and $4 \mathrm{mg} / \mathrm{l}$, respectively, corresponding to zone diameters of less than 12,19 , and $18 \mathrm{~mm}$. Non-typable or spontaneously agglutinating $E$ coli cannot adequately be classified by serotyping (see accompanying paper), so in addition to $\mathrm{O}$ typing ${ }^{11}$ we used multilocus enzyme electrophoresis to identify $E$ coli isolates before and after antibacterial treatment; with this technique identification of all isolates is possible. ${ }^{12}$

Radiological investigations-Intravenous urography was performed in all patients and voiding cystourethrography in all but two.

Statistical analyses were by Fisher's exact test and the sign test.

\section{Results}

PHENOXYMETHYLPENICILLIN TREATED GROUP

After treatment with phenoxymethylpenicillin three different clinical patterns emerged - namely, development of symptomatic urinary tract infections, persistence or reappearance of asymptomatic bacteriuria, and eradication of bacteriuria without recurrence (table II).

Symptomatic infections-Six girls developed acute pyelonephritis and one acute cystitis. All the symptomatic recurrences were caused by strains of $E$ coli that were different from the pretreatment strain. In no case did the symptomatic recurrence occur more than five months after treatment.

Persistence or reappearance of asymptomatic bacteriuriaNon- $E$ coli bacteriuria was found in nine patients. Enterococci and Staphylococcus epidermidis appeared in two patients each. One girl (case $3 b$ ) had enterococci in two cultures before switching to a new $E$ coli strain, which caused acute pyelonephritis. Two girls changing to Klebsiella carried these organisms for several years while remaining free of symptoms.Enterobacter, Providencia, and Pseudomonas were isolated once each and were then followed by new $E$ coli strains without the development of symptoms. On 18 occasions the asymptomatic bacteriuria after treatment with phenoxymethylpenicillin was caused by new $E$ coli strains. In eight of these there was a change from one $\mathrm{O}$ type to another. In the remaining 10 strains were nontypable and changes were identified by multilocus enzyme electrophoresis. In one girl (case 3c) there was a change from $E$ coli $\mathrm{O} 75$ to $\mathrm{O} 25$, though the electrophoretic type was the same in both strains. Persistence or recolonisation by the same $E$ coli strain occurred in seven patients. Five had negative urine cultures before the same strain reappeared.

Eradication of bacteriuria without recurrenceFive girls became abacteriuric after phenoxymethylpenicillin and had no further urinary infections during a mean follow up of 3.5 years.

\section{ERYTHROMYCIN TREATED GROUP}

No girl had a symptomatic infection after treatment with erythromycin, and no non- $E$ coli strains were
TABLE II-Characteristics of Gram negative bacterial isolates before and after use of phenoxymethylpenicillin to treat 46 episodes in 40 patients and clinical outcome

\begin{tabular}{|c|c|c|c|c|}
\hline \multirow{3}{*}{$\begin{array}{l}\text { Case } \\
\mathrm{No}^{\star}\end{array}$} & \multicolumn{3}{|c|}{ Bacterial characteristics } & \multirow{3}{*}{$\begin{array}{l}\text { Clinical } \\
\text { outcome }\end{array}$} \\
\hline & \multicolumn{2}{|c|}{ O Typet } & \multirow{2}{*}{$\begin{array}{c}\text { Electrophoretic } \\
\text { type }\end{array}$} & \\
\hline & Before & After & & \\
\hline la & 9 & 6 & Change & Pyelonephritis \\
\hline 2 & 85 & 1 & Change & Pyelonephritis \\
\hline $3 a$ & 25 & NT & Change & Pyelonephritis \\
\hline 4 & NT & NT & Change & Pyelonephritis \\
\hline $5 a$ & NT & 1 & Change & Pyelonephritis \\
\hline 6 & NT & 4 & Change & Pyelonephritis \\
\hline 7 & 117 & 51 & Change & Cystitis \\
\hline 8 & NT & Non- $E$ Coli & - & $\begin{array}{c}\text { Asymptomatic } \\
\text { bacteriuria }\end{array}$ \\
\hline $3 b$ & 8 & Non-E Coli & - & $\begin{array}{c}\text { Asymptomatic } \\
\text { bacteriuria }\end{array}$ \\
\hline 9 & 21 & Non-E Coli & - & $\begin{array}{c}\text { Asymptomatic } \\
\text { bacteriuria }\end{array}$ \\
\hline 10 & 75 & Non- $E$ Coli & - & $\begin{array}{c}\text { Asymptomatic } \\
\text { bacteriuria }\end{array}$ \\
\hline $11 \mathrm{a}$ & NT & Non-E Coli & - & $\begin{array}{c}\text { Asymptomatic } \\
\text { bacteriuria }\end{array}$ \\
\hline 12 & 2 & Non-E Coli & - & $\begin{array}{c}\text { Asymptomatic } \\
\text { bacteriuria }\end{array}$ \\
\hline 13 & 7 & Non-E Coli & - & $\begin{array}{c}\text { Asymptomatic } \\
\text { bacteriuria }\end{array}$ \\
\hline 14 & 1 & Non- $E$ Coli & - & $\begin{array}{c}\text { Asymptomatic } \\
\text { bacteriuria }\end{array}$ \\
\hline 15 & NT & Non-E Coli & - & $\begin{array}{c}\text { Asymptomatic } \\
\text { bacteriuria }\end{array}$ \\
\hline $16 a$ & 16 & 1 & Change & $\begin{array}{c}\text { Asymptomatic } \\
\text { bacteriuria }\end{array}$ \\
\hline $16 \mathrm{~b}$ & 1 & 9 & Change & $\begin{array}{c}\text { Asymptomatic } \\
\text { bacteriuria }\end{array}$ \\
\hline $16 c$ & 9 & 8 & Change & $\begin{array}{c}\text { Asymptomatic } \\
\text { bacteriuria }\end{array}$ \\
\hline 17 & 1 & 18 & Change & $\begin{array}{c}\text { Asymptomatic } \\
\text { bacteriuria }\end{array}$ \\
\hline $11 b$ & 20 & 75 & Change & $\begin{array}{c}\text { Asymptomatic } \\
\text { bacteriuria }\end{array}$ \\
\hline 18 & 75 & 18 & Change & $\begin{array}{c}\text { Asymptomatic } \\
\text { bacteriuria }\end{array}$ \\
\hline 19 & 2 & 8 & Change & $\begin{array}{c}\text { Asymptomatic } \\
\text { bacteriuria }\end{array}$ \\
\hline $3 c$ & 75 & 25 & Same & $\begin{array}{c}\text { Asymptomatic } \\
\text { bacteriuria }\end{array}$ \\
\hline $20 \mathrm{a}$ & 8 & NT & Change & $\begin{array}{c}\text { Asymptomatic } \\
\text { bacteriuria }\end{array}$ \\
\hline 21 & NT & 1 & Change & $\begin{array}{c}\text { Asymptomatic } \\
\text { bacteriuria }\end{array}$ \\
\hline $22 a$ & NT & 15 & Change & $\begin{array}{c}\text { Asymptomatic } \\
\text { bacteriuria }\end{array}$ \\
\hline 23 & NT & 22 & Change & $\begin{array}{c}\text { Asymptomatic } \\
\text { bacteriuria }\end{array}$ \\
\hline 24 & NT & 15 & Change & $\begin{array}{c}\text { Asymptomatic } \\
\text { bacteriuria }\end{array}$ \\
\hline 25 & NT & 13 & Change & $\begin{array}{c}\text { Asymptomatic } \\
\text { bacteriuria }\end{array}$ \\
\hline 26 & NT & NT & Change & $\begin{array}{c}\text { Asymptomatic } \\
\text { bacteriuria }\end{array}$ \\
\hline $\mathrm{lb}$ & NT & NT & Change & $\begin{array}{c}\text { Asymptomatic } \\
\text { bacteriuria }\end{array}$ \\
\hline 27 & NT & NT & Change & $\begin{array}{c}\text { Asymptomatic } \\
\text { bacteriuria }\end{array}$ \\
\hline 28 & NT & NT & Change & $\begin{array}{c}\text { Asymptomatic } \\
\text { bacteriuria }\end{array}$ \\
\hline 29 & 13 & 13 & Same & $\begin{array}{c}\text { Asymptomatic } \\
\text { bacteriuria }\end{array}$ \\
\hline 30 & 2 & 2 & Same & $\begin{array}{c}\text { Asymptomatic } \\
\text { bacteriuria }\end{array}$ \\
\hline 31 & 4 & 4 & Same & $\begin{array}{c}\text { Asymptomatic } \\
\text { bacteriuria }\end{array}$ \\
\hline $32 a$ & 75 & 75 & Same & $\begin{array}{c}\text { Asymptomatic } \\
\text { bacteriuria }\end{array}$ \\
\hline 33 & 6 & 6 & Same & $\begin{array}{c}\text { Asymptomatic } \\
\text { bacteriuria }\end{array}$ \\
\hline 34 & NT & 12 & Same & $\begin{array}{c}\text { Asymptomatic } \\
\text { bacteriuria }\end{array}$ \\
\hline 35 & NT & 4 & Same & $\begin{array}{c}\text { Asymptomatic } \\
\text { bacteriuria }\end{array}$ \\
\hline 36 & 2 & - & - & No recurrence \\
\hline 37 & NT & - & - & No recurrence \\
\hline 38 & NT & - & - & No recurrence \\
\hline 39 & NT & - & - & No recurrence \\
\hline 40 & NT & - & - & No recurrence \\
\hline
\end{tabular}

$\star a, b, c=$ Episodes $1,2,3$ in patients treated more than once $+\mathrm{NT}=$ Non-typable.

found (table III). New $E$ coli strains were seen in two girls. In one of these (case 41) the change was detectable only by multilocus enzyme electrophoresis; in the other (case 32b) it was detected by change of $\mathrm{O}$ type despite an identical electrophoretic pattern. Persistence or recolonisation by the same $E$ coli strain was found after the remaining 18 courses of treatment. In 
TABLE III - Characteristics of Gram negative bacterial isolates befor and after use of erythromycin to treat 20 episodes in 16 patients and clinical outcome

\begin{tabular}{|c|c|c|c|c|}
\hline \multirow{3}{*}{$\begin{array}{l}\text { Case } \\
\mathrm{No}^{\star}\end{array}$} & \multicolumn{3}{|c|}{ Bacterial characteristics } & \multirow{3}{*}{$\begin{array}{l}\text { Clinical } \\
\text { outcome }\end{array}$} \\
\hline & \multicolumn{2}{|c|}{ O Type† } & \multirow{2}{*}{$\begin{array}{c}\text { Electrophoretic } \\
\text { type }\end{array}$} & \\
\hline & Before & After & & \\
\hline 41 & 2 & NT & Change & $\begin{array}{c}\text { Asymptomatic } \\
\text { bacteriuria }\end{array}$ \\
\hline $32 b$ & 6 & 22 & Same & $\begin{array}{c}\text { Asymptomatic } \\
\text { bacteriuria }\end{array}$ \\
\hline lc & 8 & 8 & Same & $\begin{array}{c}\text { Asymptomatic } \\
\text { bacteriuria }\end{array}$ \\
\hline 42 & 6 & 6 & Same & $\begin{array}{c}\text { Asymptomatic } \\
\text { bacteriuria }\end{array}$ \\
\hline $22 b$ & 15 & 15 & Same & $\begin{array}{c}\text { Asymptomatic } \\
\text { bacteriuria }\end{array}$ \\
\hline 43 & 75 & 75 & Same & $\begin{array}{c}\text { Asymptomatic } \\
\text { bacteriuria }\end{array}$ \\
\hline 44 & 25 & 25 & Same & $\begin{array}{c}\text { Asymptomatic } \\
\text { bacteriuria }\end{array}$ \\
\hline $45 \mathrm{a}$ & 75 & NT & Same & $\begin{array}{c}\text { Asymptomatic } \\
\text { bacteriuria }\end{array}$ \\
\hline 46 & 33 & NT & Same & $\begin{array}{c}\text { Asymptomatic } \\
\text { bacteriuria }\end{array}$ \\
\hline 47 & NT & 1 & Same & $\begin{array}{c}\text { Asymptomatic } \\
\text { bacteriuria }\end{array}$ \\
\hline $20 \mathrm{~b}$ & NT & NT & Same & $\begin{array}{c}\text { Asymptomatic } \\
\text { bacteriuria }\end{array}$ \\
\hline $20 c$ & NT & NT & Same & $\begin{array}{c}\text { Asymptomatic } \\
\text { bacteriuria }\end{array}$ \\
\hline $5 b$ & NT & NT & Same & $\begin{array}{c}\text { Asymptomatic } \\
\text { bacteriuria }\end{array}$ \\
\hline $48 a$ & NT & NT & Same & $\begin{array}{c}\text { Asymptomatic } \\
\text { bacteriuria }\end{array}$ \\
\hline $48 b$ & NT & NT & Same & $\begin{array}{c}\text { Asymptomatic } \\
\text { bacteriuria }\end{array}$ \\
\hline $48 c$ & NT & NT & Same & $\begin{array}{c}\text { Asymptomatic } \\
\text { bacteriuria }\end{array}$ \\
\hline 49 & NT & NT & Same & $\begin{array}{c}\text { Asymptomatic } \\
\text { bacteriuria }\end{array}$ \\
\hline 50 & NT & NT & Same & $\begin{array}{c}\text { Asymptomatic } \\
\text { bacteriuria }\end{array}$ \\
\hline 51 & NT & NT & Same & $\begin{array}{c}\text { Asymptomatic } \\
\text { bacteriuria }\end{array}$ \\
\hline $45 b$ & NT & NT & Same & $\begin{array}{c}\text { Asymptomatic } \\
\text { bacteriuria }\end{array}$ \\
\hline
\end{tabular}

$\star \mathrm{a}, \mathrm{b}, \mathrm{c}=$ Episodes 1, 2, 3 in patients treated more than once. $+\mathrm{NT}=$ Non-typable.

TABLE IV-Effect of treatment with phenoxymethylpenicillin and erythromycin on bacteriuria. Figures in parentheses indicate first treatment course of each patient

\begin{tabular}{lcc}
\hline & Phenoxymethylpenicillin & Erythromycin \\
\hline $\begin{array}{l}\text { Same strain } \\
\begin{array}{l}\text { Change of strain or elimination } \\
\text { of bacteriuria without } \\
\text { recurrence }\end{array}\end{array}$ & $7(7)$ & $18(10)$ \\
& $39(33)$ & $2(1)$
\end{tabular}

five of these the same $\mathrm{O}$ type was found before and after erythromycin. In 13 cases one or both strains could not be $O$ typed but electrophoretic analysis showed the same pattern in each bacterial pair. Urine cultures were obtained on seven occasions during treatment with erythromycin, and all showed bacterial growth.

\section{PHENOXYMETHYLPENICILLIN VERSUS ERYTHROMYCIN}

Table IV summarises the effects of phenoxymethylpenicillin and erythromycin on urinary isolates. The difference between the two treatment groups was highly significant and remained so when only the first treatment of each patient was considered $(p<0.001$, Fisher's exact test).

Sensitivity of bacteria-In the phenoxymethylpenicillin treated group antibiotic resistance was tested in 44 strains obtained before treatment and 35 strains obtained after treatment. Two strains before treatment and six strains after treatment were not available for testing. In the erythromycin treated group 20 strains before treatment and 19 after treatment were tested; one strain was not available. All isolates were resistant to phenoxymethylpenicillin in vitro. Sensitivity to ampicillin changed to resistance in eight girls in the penicillin treated group, but no such change occurred after erythromycin. The reverse pattern was not seen $(p<0.01$, sign test). All but three strains were resistant to erythromycin in vitro. The three strains had zone diameters of 18,18 , and $19 \mathrm{~mm}$, indicating that they were close to resistance.

\section{Discussion}

In this series phenoxymethylpenicillin had a dramatic effect on the bacteria in children with asymptomatic bacteriuria. Despite resistance to the drug in vitro the bacteriuria was eradicated with only a few exceptions, and a change of strain occurred after 34 of the 46 courses. The reason was probably the high urinary concentration of phenoxymethylpenicillin during treatment. The effect of penicillin on Gram negative bacteria in the urine has been described. ${ }^{13}$

Only five of the 40 girls treated with phenoxymethylpenicillin remained free of recurrences. In the rest recolonisation occurred. In most cases the patients remained free of symptoms; nevertheless, there were seven episodes of acute pyelonephritis in six patients, illustrating how the natural course of asymptomatic bacteriuria may be altered by unintentional eradication of the bacteria. This mechanism might explain the occurrence of symptomatic infections in untreated groups in other series. ${ }^{34}$

The ecological effect of phenoxymethylpenicillin was evident in this study - for example, as manifested by the many non- $E$ coli isolates after treatment (nine of 41 positive urine cultures). There was also a significant increase in the number of ampicillin resistant bacteria after treatment. These ecological effects were unexpected as phenoxymethylpenicillin is considered not to affect the faecal flora.${ }^{14}$ An alternative explanation is that the urine creates a penicillin rich environment in the periurethral area which favours a selection of bacteria resistant to penicillin and ampicillin.

Erythromycin, on the other hand, rarely affected the bacteriuria, and a change of strain was seen after only two of 20 courses. The antibacterial effect against aerobic Gram negative bacteria is very low except at a urinary $\mathrm{pH}$ of at least $8 \cdot 0 .{ }^{\text {is }}$ The strain most sensitive to erythromycin was recovered from the urine even during treatment. Only two girls had a new strain after treatment in neither case accompanied by symptoms.

Our findings also disclose an increased risk of acute pyelonephritis after elimination of the bacteriuria in girls with asymptomatic disease. The proneness to urinary infections and thus the recurrence rates were high in these patients. Each change of strain carries the risk of acquiring a more virulent strain, which may cause acute pyelonephritis. By contrast, in the absence of antibiotic treatment spontaneous changes of strain were uncommon (see accompanying paper).

The occurrence of the same electrophoretic type but different $\mathrm{O}$ type in two pairs of isolates (cases $3 \mathrm{c}$ and $32 \mathrm{~b}$; tables II, III) was surprising. The most probable explanation is that the patients acquired new strains which shared the same isoenzyme markers tested but which would be found to differ in a more extensive screening of isoenzymes. The degree of identity, however, can finally be established only by DNA analysis Nevertheless, the finding suggests that discrete changes in surface antigens may occur. As surface antigens have been used as clonal identification markers, this would upset the current theory on the stable clonal structure of $E$ coli populations.

In view of the high incidence of symptomatic urinary tract infections after treatment with phenoxymethylpenicillin antibacterial agents which eradicate the strains in asymptomatic bacteriuria should be avoided. In patients in whom maintenance of the pretreatment bacterial strain is desirable erythromycin may be considered as an alternative. 
The study was supported by grants from the Swedish Medical Research Council, the Lundberg Foundation for Scientific Research, and the Swedish Board for Technical Development. We also acknowledge the skilful technical work of Susanne Schmeisser.

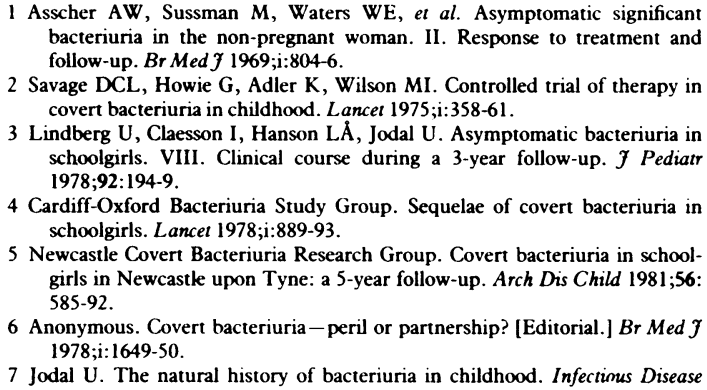
bacteriuria in the non-pregnant

2 Savage DCL, Howie G, Adler K, Wilson MI. Controlled trial of therapy in covert bacteriuria in childhood. Lancet 1975; i:358-61.

3 Lindberg U, Claesson I, Hanson LÅ, Jodal U. Asymptomatic bacteriuria in schoolgirls. VIII. Clinical course during a 3-year follow-up. $\mathcal{J}$ Pediatr 1978;92:194-9.

4 Cardiff-Oxford Bacteriuria Study Group. Sequelae of covert bacteriuria in schoolgirls. Lancet 1978; : $889-93$

5 Newcastle Covert Bacteriuria Research Group. Covert bacteriuria in schoolgirls in Newcastle upon Tyne: a 5-year follow-up. Arch Dis Child 1981;56: 585-92.

6 Anonymous. Covert bacteriuria-peril or partnership? [Editorial.] $\mathrm{Br} \mathrm{Med} \mathcal{J}$ 1978;i:1649-50.

7 Jodal U. The natural history of bacteriuria in childhood. Infectious Disease Clinics of North America 1987;1:713-29.
8 Jodal $\mathrm{U}$, Lindberg $\mathrm{U}$, Lincoln $\mathrm{K}$. Level diagnosis of symptomatic urinary tract infections in childhood. Acta Paediatr Scand 1975;64:201-8.

Hodson CJ, Wilson S. Natural history of chronic pyelonephritic scarring. BrMed f 1965;ii:191-4.

10 Ericsson HM, Sherris JC. Antibiotic sensitivity testing. Acta Pathologica et Microbiologica Scandinavica (B) 1971;217(suppl):1-90.

11 Lidin-Janson G, Falsen E, Jodal U, Kaijser B, Lincoln K. Characteristics of antibiotic-resistant Escherichia coli in the rectum of healthy schoolchildren. f Med Microbiol 1977; 10:299-308.

12 Caugant DA, Levin BR, Orskov I, Orskov F, Svanborg-Edén C, Selander RK. Genetic diversity in relation to serotype of Escherichia coli. Infect Immun 1985; 49:407-13

13 Stamey T, Govan D, Palmer J. The localization and treatment of urinary tract infections: the role of bactericidal urine levels as opposed to serum levels. Medicine 1965;44:1-26.

14 Heimdahl A, Nord CE. Effect of phenoxymethylpenicillin and clindamycin on the oral, throat and faecal microflora of man. Scand f Infect Dis 1979;11 233-42.

15 Zinner SK, Sabath LD, Casey J, et al. Erythromycin and alkalinisation of the urine in the treatment of urinary tract infections due to Gram-negative bacilli. Lancet $1971 ; \mathrm{i}: 1267$

(Accepted 23 fanuary 1989)

\title{
Self referral to an accident and emergency department for another opinion
}

\author{
Christopher S Jones, Alastair McGowan
}

\begin{abstract}
Objective-To determine whether patients re-
\end{abstract} ferring themselves to an accident and emergency department for another opinion after consulting their general practitioner present with serious illness, show any risk factors for being admitted, or are more likely to be patients of particular practitioners.

Design-Six month prospective survey.

Setting-District general hospital's accident and emergency department, receiving 42000 new patients a year.

Patients-180 Patients identified as attending for another opinion having already consulted a general practitioner.

Interventions-Classified as admission, referral to specialist clinic, follow up in accident and emergency department, or referral back to general practitioner.

End point-Admission, with an analysis of admitted patients.

Measurements and main results-General outcome, diagnostic category, age, time of attendance, time since seen by general practitioner, and name of general practitioner were recorded. Forty seven patients were admitted, 99 were discharged back to the general practitioner (62 without a letter), and two died. Patients were most likely to be admitted if they attended within 24 hours after seeing a general practitioner, were aged under 5 , or presented with respiratory or gastrointestinal complaints. Some general practitioners were overrepresented.

Conclusions - Important disorders present in this way, and therefore these patients should be seen by a doctor. Information about these attendances could be useful to general practitioners in reviewing their performance.

\section{Introduction}

In this accident and emergency department we noticed an increasing tendency for patients to refer themselves for another opinion after consulting their general practitioner. We thought that this resulted from a breakdown in communication between some patients and their doctors, which resulted in patients not being referred. One previous study has measured this tendency,' but little else is known about these attendances. These patients may be regarded as inappropriately attending the accident and emergency department, and some departments send them back to their general practitioner. ${ }^{2}$ This may be unsafe if important illness presents in this way.

Our aims were, firstly to estimate the amount of serious illness presented in this way as indicated by the general outcome in all patients and medical outcomes in patients admitted; secondly, to analyse some basic demographic features to see if particular groups were at increased risk of being admitted; and, thirdly, to determine whether these attendances were sporadic or whether particular practitioners were overrepresented. This information might be helpful to general practitioners when examining their techniques of consultation or referral.

\section{Subjects and methods}

We carried out a prospective survey from 1 November 1987 to 30 April 1988. Patients referring themselves for another opinion after consulting their general practitioner were identified by staff at reception and their record cards marked. They were defined as those with problems for which they had previously consulted their general practitioner and who had not been referred to the accident and emergency department. Patients who claimed that they were unable to contact or obtain a visit from their general practitioner and those who had been told to attend if their conditions deteriorated were excluded. These exclusions were made to confine the study to patients who deliberately had not reconsulted the doctor they had already seen.

The data analysed were diagnostic category, age, sex, time of attendance, time elapsed since general practitioner had been consulted, whether a letter had been sent to the general practitioner, the name of the general practitioner, and what happened to the patient after attending. The hospital records of those patients admitted were further inspected for length of stay, final diagnosis, and outcome. When appropriate the significance of the data was assessed by the $\chi^{2}$ test with Yates's correction. 